\title{
PAJAK KARBON, KERUSAKAN KARBON, DAN PERTUMBUHAN EKONOMI DI LIMA BELAS NEGARA SELAMA 27 TAHUN
}

\author{
Riris Rotua Sitorus' ; Tangguh Pratysto \\ Universitas 17 Agustus 45 Jakarta \\ riris.sito@gmail.com
}

\begin{tabular}{|c|c|}
\hline Keyword & Abstract \\
\hline $\begin{array}{l}\text { Carbon Tax, Real Gross Domestic } \\
\text { Product Per Capita Growth, } \\
\text { Greenhouse Gases, CO2, Global } \\
\text { Warming, Emissions }\end{array}$ & $\begin{array}{l}\text { The purpose of this study is to analyze the effect of carbon tax and } \\
\text { carbon damage on economic growth in I } 5 \text { (fifteen) countries from } 1990 \\
\text { to } 20 \text { I } 7 \text {. Based on the results of research by weather scientists who } \\
\text { stated that there are } 50-500 \text { possibilities to limit global warming at } 2 \\
\text { degrees Celsius above average global temperatures from pre-industrial } \\
\text { times throughout the } 2 \text { Ist century.Global warming is caused by } \\
\text { cumulative carbon emissions which continue to increase from year to } \\
\text { year, resulting in threats to the world's sustainable development. } \\
\text { Therefore carbon production must be limited by imposing a tax on } \\
\text { carbon so that economic growth can run normally and even } \\
\text { increase.Researchers used the open economy model Y }=(C, I, G, N X) \\
\text { namely final household consumption expenditure (C), foreign direct } \\
\text { investment (I), government final consumption general expenditure }(G) \text {, } \\
\text { and import export per GDP (NX) for control variables. The researcher } \\
\text { also used the Cobb-Douglas } Y=(K \text {, L) production function, namely gross } \\
\text { capital formation (K) and the ratio of working people per population (L) } \\
\text { to the control variable. The data used were panel data in I5 countries } \\
\text { that applied Carbon Tax from I } 990 \text { to } 20 \text { I } 7 \text {. Researchers used GLS } \\
\text { (Generalized Least Squares) estimation to analyze the effect of carbon } \\
\text { tax and carbon destruction on economic growth.The result is a carbon } \\
\text { tax can stimulate the growth of real gross domestic product per capita } \\
\text { and carbon damage hinder economic growth. }\end{array}$ \\
\hline
\end{tabular}

(C2018 JMB, All right reserved

\section{PENDAHULUAN}

\section{Latar Belakang Masalah}

Perubahan cuaca adalah masalah umum utama (Stavin, 20II; Martin et al, 20l4), yang disebabkan antropogenik emisi gas rumah kaca (GHG) seperti karbon dioksida (CO2) dan diperkirakan menyebabkan konsekuensi ekologi dan ekonomi yang parah (IPCC, 2007; Martin et al, 20l4). Ilmuwan cuaca sudah memperingatkan terdapat 50-500 kemungkinan membatasi pemanasan global pada 2 derajat celcius diatas rata-rata temperatur global dari masa praindustrial ke sepanjang abad ke-2l. Emisi karbon kumulatif antara tahun 20II dan 2050 perlu dibatasi pada 110 Gigaton karbon dioksida (Gt $\mathrm{CO} 2$ ) atau 300 Gigaton karbon (GtC) (Allen et al, 2009; Meinshausen et al, 2009; Ploeg dan
Rezai, 2016). Emisi beracun mempunyai efek merugikan pada orang yang hidup saat ini, sedangkan efek peningkatan $\mathrm{CO} 2$ yang menyebabkan perubahan cuaca yang akan ditanggung generasi masa depan (David dan Montag, 20I4).

Produksi dan utilisasi sumber daya hidrokarbon meningkatkan kekhawatiran tentang isu pemanasan global (Taylor et al, 2017). CO2 adalah salah satu gas rumah kaca yang menyebabkan perubahan cuaca global atau pemanasan global. Pajak karbon sebagai pengurang gas rumah kaca sangat disarankan oleh para cendikiawan dan organisasi internasional (Zhou et al, 20ll). Pajak karbon secara ekonomi signifikan untuk mengurangi emisi karbon, dimana emisi karbon disebabkan oleh produk bahan bakar fosil seperti bensin, 
avtur, dan gas perlu dikurangi konsumsi bahan bakar dan emisi CO2-nya (Zhou et al, 20ll). Untuk stategi jangka panjang mengurangi emisi gas rumah kaca, pajak karbon secara bertahap mendapatkan perhatian komunitas internasional pada efisiensi ekonomi dan peran positifnya dalam konservasi energi dan proteksi lingkungan (Zhou et al, 20II).

Pajak karbon sebagai pendekatan berbasis pasar, merupakan metode mitigasi yang sangat bagus (Zhou et al, 20l I). Pertama, karena hal ini membuat perusahaan untuk mengontrol emisi CO2 melalui perubahan harga (Zhou et al, 20II). Kedua, biaya implementasi pajak karbon relatif rendah karena bisa disesuaikan pada basis pajak yang sudah ada (Zhou et al, 20I I). Ketiga, karena hal ini bisa menciptakan reputasi dan posisi yang bagus untuk negosiasi perubahan iklim (Zhou et al, 20I I). Di bawah keberadaan pajak karbon, sumber polusi dan konsumsi akhir energi bisa dikontrol dengan lebih baik (Fang et al, 20I6).

Hasil dari pajak karbon bisa digunakan secara stratejik untuk menyediakan bantuan jangka panjang dan stabil pada usaha penelitian dan pengembangan untuk sumber energi, penggunaan energi, dan mitigasi emisi (Stram, 20I4).

\section{Rumusan Masalah}

Perumusan masalah yang akan dibahas pada penelitian ini, yaitu:

I. Apakah Pajak Karbon dapat menstimulasi Pertumbuhan Ekonomi?

2. Apakah Kerusakan Karbon menghambat Pertumbuhan Ekonomi?

\section{TINJAUAN PUSTAKA}

\section{Pajak Karbon}

Menurut Zhou et al (20II) jumlah $\mathrm{CO} 2$ hampir $80 \%$ dari gas rumah kaca (GHGs) dan sekitar $90 \%$ emisi CO2 berasal dari pembakaran bahan bakar fosil. Berdasarkan Sokolov et al (2009) dan Alton (2014) mengestimasi bahwa tanpa mitigasi secara global, jika dibandingkan dengan akhir abad ke 20, maka terdapat $50 \%$ kemungkinan temperatur global akan naik 5 derajat celcius atau lebih di tahun 2100, sedangkan peluang untuk naik dibawah 2 derajat adalah nol.

Implementasi karbon pajak berfungsi untuk menginisiasi transformasi "greener" ekonomi dan lebih cepat mengurangi emisi di masa depan (Alton, 20l4). Van Heerden et al (2006) dan Alton et al (2014) menemukan "triple dividend" yaitu mengurangi emisi $\mathrm{CO} 2$, mengurangi kemiskinan, dan meningkatkan PDB, hal ini mungkin jika pendapatan dari pajak lingkungan dipakai untuk mengurangi harga makanan. Pajak karbon dan ETS (Emissions Trading System) dianggap sebagai instrumen pembentukan harga karbon yang paling efektif untuk mengurangi emisi (OCDE, 2013 dan Calderon et al, 2016).Pendapatan pajak dari pajak karbon bisa untuk mengurangi pajak lainnya di dalam sistem (Goulder, 1995 dan Calderon et al, 2016).Contohnya, pendapatan pajak dari pajak karbon karbon bisa mengurangi pajak tenaga kerja sehingga dapat menghasilkan biaya ekonomi yang lebih rendah (Calderon et al, 2016).

Penerimaan pajak karbon sejak akhir tahun 2000 s, telah sering secara eksplisit dibenarkan karena kemampuannya dalam menciptakan pendapatan yang signifikan sebagai pengganti pajak tenaga kerja atau membantu mengurangi resesi karena defisit pemerintah (contoh: Irlandia, Islandia) dan mempunyai kemampuan untuk mengurangi emisi karbon dioksida (Carl, Jeremy dan Fedor, David; 2016). Pengaruh pajak karbon pada investasi terutama pada carbon finance melalui green financial akan menarik investor asing (Zhenxiang, 20I I).

\section{Perkembangan Pajak Karbon dan ETS}

Berikut ini adalah tabel perkembangan pajak karobin internasional.

Tabel I. Perkembangan Pajak Karbon Internasional

\begin{tabular}{|l|l|l|lr|}
\hline Finland carbon tax (1990) & $\begin{array}{l}\text { Denmark carbon tax } \\
(1992)\end{array}$ & $\begin{array}{l}\text { Switzerland carbon tax } \\
(2008)\end{array}$ & France carbon tax (20I4) \\
\hline Poland carbon tax (1990) & Latvia carbon tax (1995) & Iceland carbon tax (20I0) & $\begin{array}{l}\text { Mexico carbon } \\
(2014)\end{array}$ \\
\hline $\begin{array}{l}\text { Sweden carbon tax } \\
(1991)\end{array}$ & $\begin{array}{l}\text { Slovenia carbon tax } \\
(1996)\end{array}$ & Ireland carbon tax (2010) & $\begin{array}{l}\text { Portugal carbon tax } \\
(2015)\end{array}$ \\
\hline $\begin{array}{l}\text { Norway carbon tax } \\
(1991)\end{array}$ & Estonia carbon tax (2000) & Japan carbon tax (2012) & \\
\hline
\end{tabular}

Sumber: The World Bank dan Ecofys, 2016 
Pajak karbon telah diimplementasikan atau dijadwalkan untuk dimulai di 15 juridiksi negara seperti yang ditampilkan tabel. Detail perkembangan utama pada pajak karbon dan ETS di tahun terakhir ini dijelaskan sebagai berikut.

\section{Uni Eropa}

Untuk memberikan stabilitas harga dan prediktabilitas yang lebih baik dalam EU ETS (European Union Emissions Trading System), cadangan stabilitas pasar dilegislasi di bulan Oktober 2015 dan akan mulai membentuk pasokan tunjangan pada Januari 2019 (The World Bank dan Ecofys, 2016). Selain itu, pada bulan Juli 2015, European Comission mengajukan proposal untuk merevisi EU ETS setelah tahun 2020 (The World Bank dan Ecofys, 2016).Peningkatan faktor reduksi tahunan 1.74-2.2 persen, lebih tepat sasaran dan lebih mengikuti aturan terbaru untuk alokasi tunjangan pada sektor yang mempunyai risiko kebocoran karbon tertinggi (The World Bankdan Ecofys, 2016). Kemudian pembentukan dana untuk membiayai inovasi rendah karbon dalam industri dan modernisasi sektor energi di negara anggota yang berpenghasilan rendah (The World Bank dan Ecofys, 2016). Namun proposal tidak memasukkan provisi untuk penggunaan kredit internasional setelah tahun 2020.Dua badan legislatif Uni Eropa lainnya, European Council dan Parliament, saat ini sedang membahas proposalnya (The World Bank dan Ecofys, 2016).

2. Denmark

Di tahun 1993, Denmark mulai memungut pajak karbon untuk industri dan rumah tangga (Zhenxiang, 20II). Pajak karbon Denmark mencakup emisi pemakaian minyak, batu bara, listrik, dan pembakaran sampah (Carl, Jeremy dan Fedor, David; 2016). Cakupan pajak karbon meluas secara signifikan dalam Green Tax Package di 1996.Saat ini, karbon dioksida dan pajak energi dilakukan sebagai pelengkap (Carl, Jeremy dan Fedor, David; 2016).Pendapatan pajak karbon Denmark \$I miliar (DKK 5.5 miliar di 20I0) per tahun dengan tingkat pajak karbon DKK 167 (\$3I) per ton karbon dioksida di 2014 (Carl, Jeremy dan Fedor, David;
2016).Tingkat pajak saat ini dibuat naik I.8\% setiap tahun, tingkat pajak tidak konsisten diantara pengguna, pajak lebih rendah untuk industri energi intensif dan pajak lebih tinggi untuk industri pemanas ruangan (Carl, Jeremy dan Fedor, David; 2016). Bisnis secara signifikan mengurangi beban pajak secara sukarela, mengikuti kesepakatan peningkatan efisiensi energi dengan Danish Energy Authority, namun pembebasan ini bisa berubah sepanjang waktu (Carl, Jeremy dan Fedor, David; 2016).

\section{Finlandia}

$\mathrm{Di}$ tahun 1990, Finlandia memulai pembentukan pajak karbon global untuk menggantikan pajak pendapatan dan pajak jasa (Zhenxiang, 20II).Pada bulan Januari 2016, tarif pajak karbon untuk bahan bakar minyak ringan dan berat, batubara, dan gas alam meningkat dari $€ 44 / \mathrm{tCO} 2$ (US $\$ 50$ / tCO2) ke $€ 54$ / tCO2 (US \$ 62 / tCO2) (The World Bank dan Ecofys, 2016). Tujuan kenaikan ini adalah untuk mendorong penggunaan biomassa dan pemanasan bahan bakar yang rendah emisi, dan meningkatkan posisi kompetitif dari gambut dan gas alam, terutama bila dibandingkan dengan batu bara (The World Bank dan Ecofys, 2016).

Sebagai salah satu yang tertua dalam karbon pajak global, pajak karbon Finlandia mencakup bahan bakar fosil, tetapi tidak diterapkan pada pembangkit listrik atau penerbangan komersial (Carl, Jeremy dan Fedor, David; 2016).Pendapatan pajak karbon $\$ 800$ juta (EUR 600juta) per tahun dengan pajak EUR 35 (\$ 45) per ton karbon dioksida pada emisi yang tertanam pada muatan karbon pemanas ruangan (Carl, Jeremy dan Fedor, David; 2016).

4. Perancis

Pajak karbon Perancis mencakup muatan karbon pada gas alam, bahan bakar minyak, dan batu bara yang belum diatur Europian Union Emission Trading System (Carl, Jeremy dan Fedor, David; 2016). Dari 2015 pajak dibuat meluas termasuk bahan bakar transportasi dan minyak pemanas.Entitas industri dicakup dalam Europian Union Emission Trading System, tetapi industri perikanan dibebaskan (Carl, Jeremy dan Fedor, David; 2016).Pendapatan pajak 
karbon secara ringkas di tahun perdana 2014 diharapkan mencapai \$452juta (EUR 340juta) dengan tingkat pajak EUR 7 (\$9.30) per ton karbon dioksida (Carl, Jeremy dan Fedor, David; 2016).Pendapatan diperkirakan mencapai \$3.3miliar (EUR 2.5miliar) dengan tingkat pajak EUR 14.50 (\$19.30) di 2015 dan $\$ 5.3$ miliar (EUR 4miliar) dengan tingkat pajak EUR 22 (\$29.20) per ton di 2016 (Carl, Jeremy dan Fedor, David; 2016). Jika ditetapkan, hal ini akan membuat pajak Perancis menjadi sistem pendapatan karbon tebesar secara global (Carl, Jeremy dan Fedor, David; 2016).

Pajak karbon di Perancis mengenakan harga karbon pada penggunaan bahan bakar fosil yang tidak tercakup oleh ETS Uni Eropa, seperti di sektor perumahan, pelayanan, dan transportasi (World Bank dan Ecofys, 2016). Tingkat pajak karbon meningkat dari l 4,5 € / tCO2 (US \$ 17 / tCO2) ke € 22 / tCO2 (US \$ 25 / tCO2) pada Januari 2016, dan akan mencapai $€ 100 /$ tCO2 (US $\$$ Il4 / tCO2) di 2030 (World Bank dan Ecofys, 2016). Pemerintah juga mengumumkan batas bawah harga karbon untuk sektor listrik di Perancis (World Bank dan Ecofys, 2016).

5. Islandia

Pajak karbon Islandia mencakup disel, bensin, bahan bakar minyak, dan gas minyak bumi cair yang belum dicakup European Union Emission Trading System (Carl, Jeremy dan Fedor, David; 2016).Pajak semula ditetapkan untuk kadaluarsa di 2012 tetapi sekarang diperpanjang tanpa batas (Carl, Jeremy dan Fedor, David; 2016).Pendapatan pajak karbon untuk 2013 diestimasi \$30juta (IKR 3.6miliar), tingkat pajak di 20 I4 ditetapkan IKR II 20 (\$I0) per ton karbon dioksida, secara otomatis meningkat 3\% per tahun (Carl, Jeremy dan Fedor, David; 2016).

6. Irlandia

Penggunaan gas alam dan minyak dicakup dalam pajak karbon sejak 2010, bahan bakar padat sejak 2013, dan lainnya yang tidak dicakup dibawah European Union Emissions Trading System (Carl, Jeremy dan Fedor, David; 2016).Pendapatan pajak karbon \$5I0juta (EUR 400juta) di 2012, tingkat pajak ditetapkan pada EUR 20
$(\$ 25.50)$ per ton karbon dioksida dari Mei 2014, dengan diskon terbatas dengan bahan bakar biomassa tertentu, termasuk gambut (Carl, Jeremy dan Fedor, David; 2016).

\section{Jepang}

Periode compliance kedua yang terkait Saitama dan Tokyo ETSs dimulai pada tanggal I April 2015 (The World Bank dan Ecofys, 2016). Target penurunan emisi dibandingkan dengan tingkat baseline emisi sebelumnya untuk bangunan kantor, penghangat distrik, dan fasilitas pendingin di periode compliance ini meningkat 15 dan 17 persen untuk Saitama dan Tokyo ETSs masing-masing (The World Bank dan Ecofys, 2016). Untuk fasilitas (industri) lainnya, targetnya meningkat menjadi 13 dan 15 persen, masing-masing (The World Bank dan Ecofys, 2016). Di awal periode compliance kedua, perdagangan antara Saitama dan Tokyo ETSs dimulai, pada Februari 2016, hanya sekitar $2.400 \mathrm{tCO} 2 \mathrm{e}$ kredit Saitama telah dibeli perusahaan yang dinaungi Tokyo ETS (The World Bank dan Ecofys, 2016).

Pajak karbon mencakup semua bahan bakar fosil dengan pengecualian untuk beberapa sektor, termasuk pertanian dan perikanan, penerbangan domestik, dan kereta api (pengecualian hanya sampai 2017) (Carl, Jeremy dan Fedor, David; 2016). Pendapatan pajak diharapkan mencapai $\$ 490$ juta (JPY 39.Imiliar) di 2012, naik ke \$3.3miliar (JPY 262 miliar) di 2016 (pada nilai tukar 2012) (Carl, Jeremy dan Fedor, David; 2016). Hal ini dimulai dengan tingkat pajak JPY I 92 (\$1.80 pada nilai tukar 2014) per ton karbon dioksida setara emisi dari April 2014, meningkat bertahap ke JPY 289 (\$2.70) di akhir 2017 (Carl, Jeremy dan Fedor, David; 2016).Pajak diimplementasikan sebagai suplemen ke energi nasional Jepang dan pajak bahan bakar yang sudah ada, dan mewakili kurang dari I\% dari total pendapatan (Carl, Jeremy dan Fedor, David; 2016).Pemerintah Jepang mengharapkan beban rumah tangga ratarata untuk pajak karbon menjadi sekitar JPY 100 (\$0.95) per bulan (Carl, Jeremy dan Fedor, David; 2016).

8. Meksico

Sejak pelaksanaan pajak karbon pada tahun 20I4, pajak ini telah menghasilkan hampir 
US\$ I miliar dalam pendapatan (World Bank dan Ecofys, 2016).Pajak karbon yang ada adalah kombinasi inisiatif iklim lainnya, misalnya, kerangka untuk pendaftaran emisi nasional dan Clean Energy Certificates yang diharapkan bisa membuka pasar karbon pada tahun 2018 (World Bank dan Ecofys, 2016).

Pajak karbon Meksiko dimaksudkan untuk mencakup penggunaan muatan karbon bahan bakar fosil yang melebihi intensitas karbon gas alam (Carl, Jeremy dan Fedor, David; 2016).Sistem pajak diperkenalkan bersama platform perdagangan kredit karbon Meksiko yang baru dan emitor besar bisa memenuhi pajak melalui pembelian kredit karbon Certified Emissions Reductions (Carl, Jeremy dan Fedor, David; 2016). Pendapatan pajak karbon Meksiko di 2014 diestimasi $\$ 870$ juta (MEXI I.5miliar) dengan tingkat pajak mulai dari MEX 10 ke 50 ( $\$ 0.80$ ke $\$ 3.80)$ per ton karbon dioksida (tergantung tipe bahan bakar), $3 \%$ dari total harga jual (Carl, Jeremy dan Fedor, David; 2016).

9. Norwegia

Di tahun 199I, Norwegia memungut pajak karbon sebesar $65 \%$ dari semua emisi CO2 (Zhenxiang, 20II).Pajak karbon Norwegia mencakup penggunaan minyak, bensin, dan gas alam dengan pembebasan sebagian dari operasi yang dicakup European Union Emissions Trading System, hal ini diestimasikan mencakup $55 \%$ emisi ekonomi (Carl, Jeremy dan Fedor, David; 2016).Tingkat pajak bervariasi luas berdasarkan bahan bakar dan sektor, satu elemen yang spesifik menargetkan pola penggunaan energi ialah produsen minyak di lepas pantai (Carl, Jeremy dan Fedor, David; 2016). Karena itu pajak karbon tidak berbasis meluas sebab berkaitan dengan muatan atau emisi karbon, pendapatan pajak karbon Norwegia tahunan sekitar $\$ 1.58$ miliar (NKR 9.3miliar) di 2013 dari kombinasi pajak karbon pada bahan bakar dan produksi minyak di lepas pantai dari 2014, tingkat pajak NKR 25-4I9 (\$4-\$67) per ton karbon dioksida, tergantung tipe bahan bakar dan pemakaian (Carl, Jeremy dan Fedor, David; 2016). Contohnya, produsen minyak di lepas pantai sejak 2013 menghadapi tingkat pajak karbon spesial
NKR 200 (\$34) untuk platform minyak dan bahan bakar gas alam pada operasi pembangkit listrik (Carl, Jeremy dan Fedor, David; 2016). Pemerintah Norwegia menerapkan tingkat pajak untuk menginsentif produsen beralih ke pembangkit listrik tenaga air daripada membuat jalur transmisi listrik dari jaringan darat (Carl, Jeremy dan Fedor, David; 2016).

Pada tahun 2016, tarif pajak karbon di Norwegia berkisar antara NOK29-436 / tCO2e (US \$ 4-53 / tCO2e), tergantung pada bahan bakar dan sektornya, dibandingkan dengan NOK25-427 / tCO2e (US \$ 3-52 / tCO2e) di tahun 2015 (The World Bank dan Ecofys, 2016). Pemerintah Norwegia sedang mempertimbangkan reformasi untuk sistem perpajakan karbon saat ini, yang akan memperkenalkan tarif pajak tunggal NOK420 / tCO2e (US \$ 5 I / tCO2e) untuk semua sektor non-ETS (The World Bank dan Ecofys, 2016).

10. Slovenia

Slovenia negara Eropa Timur pertama yang memperkenalkan sistem pendapatan karbon saat pajak diluncurkan di 1997 dengan tingkat pajak 1000 Slovene tolar (\$6.26) per ton karbon dioksida (Carl, Jeremy dan Fedor, David; 2016). Tingkat pajak menjadi 3 kali lipat di tahun berikutnya, hasilnya restrukturisasi pajak yang signifikan untuk banyak pengguna akhir dan pembebasan bahan bakar tertentu dan diskon tingkat pajak (Carl, Jeremy dan Fedor, David; 2016).Pajak ini bisa dianggap harga karbon sebenarnya sebagai ganti pajak cukai bahan bakar (Carl, Jeremy dan Fedor, David; 2016).

Pada tanggal I April, 2016, Slovenia mengadopsi hukum pajak karbon sejalan dengan aturan Uni Eropa dengan menghapus pembebasan pada gas minyak bumi cair dan gas alami (The World Bank dan Ecofys, 2016).Tingkat pajak karbon yang sekarang berlaku untuk bahan bakar fosil $€ 17 /$ tCO2e (US \$ $20 /$ tCO2e); tingkat pajak ini juga berlaku untuk bahan bakar fosil lainnya (The World Bank dan Ecofys, 2016).

II. Swedia

Di tahun 1991, Swedia mulai untuk memungut pajak karbon, selama 1987 
hingga 1994, emisi CO2 Swedish berkurang 600-800 juta ton, turun 13\% dari keseluruhan (Zhenxiang, 20II). Sebagai salah satu yang tertua dalam pajak karbon, Swedia mencakup bahan bakar fosil yang digunakan untuk pemanas dan transportasi, sama seperti pajak karbon Nordic yang berumur panjang lainnya (Carl, Jeremy dan Fedor, David; 2016). Swedia melakukan pembebasan dan modifikasi desain untuk industri energi intensif yang didesain untuk mengurangi kebocoran (Carl, Jeremy dan Fedor, David; 2016). Pendapatan pajak karbon Swedia \$ 3.68 miliar (SEK 24 miliar) di 2013, naik sekitar \$1.3 miliar per tahun dari tahun 1993 ketika program ini diluncurkan, dan relatif stabil sejak 2003, pajak saat ini merepresentasikan 0.7 \% PDB Swedia dari tahun 2014, dengan tingkat pajak karbon SKR 1076 (\$157) per ton karbon dioksida (Carl, Jeremy dan Fedor, David; 2016). Pajak karbon dioksida Swedia dideskripsikan sebagai pelengkap pajak energi Swedia yang suda ada (Carl, Jeremy dan Fedor, David; 2016).

12. Swiss

Pajak emisi karbon dioksida Swiss melebihi persentase tingkat emisi perusahaan yang diatur di tahun 1990 (Carl, Jeremy dan Fedor, David; 2016).Bahan bakar fosil untuk pemanas dan pembangkit listrik dicakup pajak karbon. Sistem cap-and trade Swiss terbaru memungkinkan emitor industri besar tidak mengikuti pajak karbon (Carl, Jeremy dan Fedor, David; 2016).. Swiss tidak berpartisipasi dalam European Union's Emission Trading System. Pendapatan pajak karbon $\$ 875$ juta (CHF 800 juta) di 2014 dengan tingkat pajak CHF 60 (\$56) per ton emisi karbon dioksida (Carl, Jeremy dan Fedor, David; 2016).Tingkat pajak ini meningkat bertahap dari CHF 12 (\$1I.20) per ton di 2008 ke CHF 36 (\$33.50) per ton selama periode 2010-20I3 (Carl, Jeremy dan Fedor, David; 2016). Pemerintah Swiss kemungkinan meningkatkan pajak di masa depan berdasar kinerja negara untuk mencapai target pengurangan emisi karbon dioksida (Carl, Jeremy dan Fedor, David; 2016).

Pada tanggal 23 Maret 2016, Switzerland's Federal Council menyetujui Paris Agreement dan mengumumkan rencana untuk merevisi Federal Act pada Reduction of $\mathrm{CO} 2$ Emissions (CO2 Act) (The World Bank dan Ecofys, 2016). Revisi CO2 Act bisa mengakibatkan peningkatan tarif pajak karbon dengan tingkat saat ini CHF84 / tCO2e (US \$ 88 / tCO2e) (The World Bank dan Ecofys, 2016). Konsultasi publik tentang revisi $\mathrm{CO} 2$ Act akan diadakan di musim panas tahun 2016, terdapat delapan putaran perundingan yang dimulai pada tahun 2011, Swiss dan Uni Eropa telah menyelesaikan negosiasi pada tanggal 25 Januari 2016 terkait dengan ETSs (The World Bank dan Ecofys, 2016). Perjanjian ini butuh untuk ditandatangani dan diratifikasi oleh kedua belah pihak sebelum diberlakukan, waktu untuk langkah ini masih terbuka (The World Bank dan Ecofys, 2016).Ketika perjanjian mulai berlaku, Swiss perlu mengintegrasi sektor penerbangan ke ETS nya agar konsisten dengan cakupan sektor ETS Uni Eropa (The World Bank dan Ecofys, 2016).

\section{Hipotesis Penelitian}

Berbagai penelitian tentang Pajak Karbon, Kerusakan Karbon yang berpengaruh terhadap Pertumbuhan Ekonomi di berbagai negara yang telah diuraikan di atas, penulis menetapkan 2 Hipotesis, yaitu:

Hipotesis Pertama $(\mathrm{HI})$ : Pajak Karbon dapat menstimulasi Pertumbuhan Ekonomi.

Hipotesis Kedua $(\mathrm{H} 2)$ : Kerusakan Karbon menghambat Pertumbuhan Ekonomi.

\section{METODOLOGI PENELITIAN}

\section{Jenis dan Sumber Data}

Jenis data yang digunakan dalam penelitian ini, yaitu jenis data sekunder. Sedangkan sumber data yang digunakan dalam penelitian ini yaitu sumber data sekunder yang berasal dari data yang tersedia pada world bank (dalam hal ini data diambil dari website milik world bank) dan sumber lain.

\section{Populasi dan Sampel}

Populasi merupakan seluruh data yang menjadi perhatian dalam ruang lingkup yangtelah di tentukan dan pada waktu yang telah di pilih (Sugiyono, 2008:II). Populasi dalam penelitian ini adalah lima belas negara di dunia yang menerapkan pajak karbon.

Sampel adalah perwakilan dari popolasi atau sebagian dari populasi yang akan di teliti 
yang dapat mewakili seluruh populasi tersebut. Penentuan sampel dalam penelitian ini yaitu penentuan sampel dengan teknik sampling probability sampling, yaitu sensus. Metode ini menetapkan bahwa populasi merupakan sample penelitian.

\section{Teknik Analisis Data}

Artikel ini menganalisa pengaruh pajak karbon dan kerusakan $\mathrm{CO} 2$ pada pertumbuhan ekonomi atau pertumbuhan PDB negara. Penulis menggunakan model perekonomian terbuka $Y=$ (C, I, G, NX) yaitu pengeluaran konsumsi final rumah tangga (C), investasi langsung asing (I), pengeluaran umum konsumsi final pemerintah (G), dan ekspor impor per PDB (NX) untuk variabel kontrol. Penulis juga menggunakan fungsi produksi Cobb-Douglas $Y=(K, L)$ yaitu pembentukan modal bruto $(K)$ dan rasio orang bekerja per populasi $(\mathrm{L})$ untuk variabel kontrol.

In Real GDP it $=\beta_{0}+\beta_{1}$ Carbon Tax it $+\beta_{2}$ In Carbon Damage it $+\beta_{3}$ Household Consumption it $+\beta_{4}$ Gross Capital Formation it $+\beta_{5}$ In FDI Inflow it $+\beta_{6}$ In Government Consumption it $+\beta_{7}$ Trade $_{i t}+$ $\beta_{8}$ Employment it $+\varepsilon_{\text {it }}$

In menandakan logaritma natural. PDB riil (Real GDP it (Y)) adalah pertumbuhan produk domestik bruto riil, data konstan dalam US \$ di tahun dasar 2010. Carbon Tax adalah variabel dummy, untuk negara yang menerapkan pajak karbon di tahun t. Pajak karbon (Carbon Tax) adalah variabel dummy, untuk negara-negara yang menerapkan pajak karbon di tahun t. Pajak karbon sama dengan I jika negara telah menerapkan pajak karbon di tahun t, pajak karbon sama dengan 0 jika negara belum menerapkan pajak karbon di tahun t.Kerusakan Karbon (Carbon Damage)adalah kerusakan $\mathrm{CO} 2$ yang diperkirakan $\$ 20$ per ton karbon (rate tahun 1995) dikali jumlah ton karbon yang dihasilkan. Konsumsi rumah tangga (Household Consumption /C) adalah konsumsi rumah tangga akhir per produk domestik bruto. Investasi (Gross Capital Formation/K) adalah pembentukan modal bruto per produk domestik bruto, (sebelumnya investasi domestik bruto) terdiri dari penambahan aktiva tetap ditambah perubahan dalam tingkat inventaris.. FDI Inflow (I) adalah investasi langsung asing, arus masuk bersih di Balance of Payment dalam US\$ saat ini. Belanja pemerintah(Government Consumption/G) adalah pengeluaran umum konsumsi final pemerintah, data konstan dalam US\$ di tahun 2010. Perdagangan(Trade/NX) adalah jumlah ekspor dan impor barang dan jasa per produk domestik bruto. Employment adalah rasio orang yang bekerja per populasi penduduk dengan usia diatas 15 tahun (L).Data yang digunakan dalam artikel ini diambil dari data The World Bank dari tahun 1990-20I5 di I5 negara yang menerapkan pajak karbon yaitu Denmark, Estonia, Finlandia, Islandia, Irlandia, Jepang Latvia Meksiko, Norwegia, Polandia, Portugal, Slovenia, Itu, dan Swiss menggunakan regresi Prais-Winsten dengan robust

\section{HASIL PENELITIAN DAN PEMBAHASAN}

Berikut ini hasil yang diperoleh dari Regresi Prais-Winsten dengan Robust.

Tabel 2. Hasil Analisis Regresi Prais-Winsten dengan Robust

\begin{tabular}{|l|l|}
\hline \multicolumn{2}{|c|}{ Variabel dependen: Pertumbuhan PDB riil per kapita } \\
\hline Variabel independen & $\begin{array}{l}\text { Koefisien } \\
\text { (Semi-robust Standard Error) }\end{array}$ \\
\hline Pajak karbon & $\begin{array}{l}1.648549 * * \\
(0.8238493)\end{array}$ \\
\hline Konsumsi rumah tangga & -0.1831192 \\
& $(0.1728819)$ \\
\hline Investasi & $0.3212888^{*} *$ \\
& $(0.1151816)$ \\
\hline Belanja pemerintah & $-1.195353^{*} * *$ \\
& $(0.2464491)$ \\
\hline Perdagangan & $0.0857374 * *$ \\
& $(0.0348943)$ \\
\hline R2 & 0.3261 \\
\hline F-Statistik & $18.42 * * *$ \\
\hline Beberapa pengamatan & 370 \\
\hline Catatan: Generalized setidaknya Square regresi, standard errors dilaporkan dalam tanda kurung \\
*** adalah tingkat signifikansin I\% \\
** adalah tingkat signifikansi 5\% \\
* adalah tingkat signifikansi 10\%
\end{tabular}


Tabel 2menggambarkan hasil analisis, model keseluruhan signifikan secara statistik dengan F-Statistik I8.42 dan $\mathrm{P}<0,0 \mathrm{I} . \mathrm{R}^{2}$ mendefinisikan persentase variablilitas variabel dependen yang digambarkan oleh variabel independen, yang menunjukkan berapa persen dari variabel independen mampu menjelaskan variabel dependen. Dalam studi ini; pajak karbon, konsumsi rumah tangga, investasi, belanja pemerintah, dan perdagangan menjelaskan $32,61 \%$ dari variasi pertumbuhan produk domestik bruto riil per kapita. Dalam tabel 2 menunjukkan pajak karbon, investasi, dan perdagangan memiliki hubungan yang positif dan signifikan terhadap pertumbuhan produk domestik bruto riil per kapita $(p<0,05)$. Kemudian belanja pemerintah memiliki hubungan yang negatif dan signifikan terhadap pertumbuhan produk domestik bruto riil per kapita $(p<0.01)$. Sementara konsumsi rumah tangga, tidak memiliki hubungan yang signifikan pada pertumbuhan produk domestik bruto riil per kapita.

Tabel 3. Tes Diagnostik

\begin{tabular}{|l|c|l|l|l|}
\hline \multicolumn{1}{|c|}{ Tes diagnostik } & Nilai & \multicolumn{1}{c|}{ Hasil } & Treatment & \multicolumn{1}{c|}{ Hasil } \\
\hline VIF Rata-rata & $\mathrm{I}, 40$ & $\begin{array}{l}\text { Non } \\
\text { Multikolinearitas }\end{array}$ & - & $\begin{array}{l}\text { Non } \\
\text { Multikolinearitas }\end{array}$ \\
\hline $\begin{array}{l}\text { Breusch-Pagan / tes Cook- } \\
\text { Weisberg }\end{array}$ & 0.0000 & Heteroskedastisitas & Robust & Homoscedasticity \\
\hline Tes Wooldridge & 0.0000 & Autokorelasi & Prais-Winsten & Non Autokorelasi \\
\hline
\end{tabular}

Berdasarkan pada tes diagnostik Tabel 3, model regresi telah lulus tes Multikolinearitas. Namun, model regresi ini terkena masalah heteroskedastisitas dan autokorelasi, sehingga penulis menggunakan regresi Prais-Winsten dengan robust untuk mengatasi masalah heterostisitas dan autokorelasi. Dengan menggunakan regresi Prais-Winsten dengan robust, model ini adalah BLUE (Best Linear Unbiased Estimator) karena memenuhi asumsiasumsi yang non-autokorelasi, homoscedastisitas dan non-multikolinearitas.

\section{KESIMPULAN DAN SARAN}

\section{Kesimpulan}

Temuan-temuan dari studi ini menunjukkan bahwa pada pertumbuhan produk domestik bruto riil per kapita secara signifikan berhubungan dengan pajak karbon, konsumsi rumah tangga, investasi, belanja pemerintah, dan perdagangan. Hasil ini menunjukkan kenaikan pajak karbon, investasi, dan perdagangan serta penurunan belanja pemerintah bisa mendorong pertumbuhan produk domestik bruto riil per kapita. Implikasi adalah kemampuan untuk memungut pajak karbon bisa mendorong pertumbuhan produk domestik bruto riil per kapita, hal ini penting bagi regulator dalam membuat keputusan strategi ekonomi.

Studi ini memiliki banyak keterbatasan. Pertama, studi ini hanya mempelajari lima belas negara-negara pajak karbon. Kedua, jangka waktu studi yang tadinya 27 tahun, berubah menjadi 26 tahun. Hal ini terjadi dikarenakan data yang tersedia (diperoleh) oleh peneliti adalah tahun 1990 sampai tahun 2015 .
Sementara data pada tahun 2016 tidak diperoleh oleh peneliti.

\section{Saran}

Untuk kajian lebih lanjut, disarankan untuk menemukan proksi tentang pajak karbon yang bisa mempengaruhi pertumbuhan ekonomi dengan jumlah negara yang lebih banyak dalam jangka waktu yang lebih lama, untuk mencapai kesimpilan yang lebih aman.

\section{DAFTAR PUSTAKA}

Allen, M., Frame, D., Huntingford, C., Jones, C., Lowe, J., Meinshausen, M., et al. (2009). Warming caused by Cumulative Carbon Emissions Towards the Trillionth tonne. Nature, 458 (7242), PP. II63-II66.

Alton, T., Arndt, C., Davies, R., Hartley, F., Makrelov, K., Thurlow, J., et al. (20I4). Introducing Carbon Taxes in South Africa. Applied Energy, I I6, pp. 344-354.

Calderon, S., Alvarez, A. C., Loboguerrero, A. M., Arango, S., Calvin, K., Kober, T., et al. (20I6). Achieving CO2 Reductions in Colombia: Effects of Carbon Taxes and Abatement Targets. Energy Economics, 56: 575-586.

Carbone, J., Morgenstern, R., Williams III, R., \& Burtraw, D. (20I3). Deficit Reduction and Carbon Taxes: Budgetary, Economic, and Distributional Impacts. Resources for the Futures.

Carl, J., \& Fedor, D. (20I6). Tracking Global Carbon Revenues: a Survey of Carbon Taxes versus Cap-and- 
Trade in the Real World. Energy Policy, 96, pp. 50-77.

David, P., \& Montag, J. (20/4). Taxing Carproduced Carbon Dioxide Emissions: Matching the Cure to the Disease. Procedia Economics and Finance, 12: III-I 20.

Fang, G., Tian, L., Fu, M., Sun, M., Du, R., \& Liu, M. (20I6). Investigation of Carbon Tax Pilot in YRD Urban Agglomerations-Analysis and Application of a Novel ESER System with Carbon Tax Constraints. Energy Procedia, 88: 290-296.

Floros, N., \& Vlachou, A. (2005). Energy Demand and Energy-Related $\mathrm{CO} 2$ Emission in Greek Manufacturing: Assessing the Impact of a Carbon Tax. Energy Economics, 25:387-4I.

Goulder, L. (1995). Environmental Taxation and Double Dividend: a Reader's Gide. International Tax Public Finance, 2: I57-I83.

Goulder, L., \& Hafstead, M. (2013). Tax Reform and Environmental Policy: Options for Recycling Revenue from a Tax on Carbon Dioxide. Resources for the Future.

IPCC. (2007). Climate Change 2007. Fourth Assessment Report. Intergovernmental Panel on Climate Change. Geneva.

Martin, R., Preux, L. B., \& Wagner, U. J. (20I4). The Impact of a Carbon Tax on Manufacturing: Evidence from Microdata. Journal of Public Economics, II7, pp. I-I4.

McKibben, W., Morris, A., \& Wilcoxen, P. (20I2). The Potential Role of a Carbon Tax in U.S. Fiscal Reform. Brookings Institution.

Meinshausen, M., Meinshausen, N., Hare, W., Raper, S., Frieler, K., Knutti, R., et al. (2009). Greenhouse gas emission targets for limiting global warming to 2" C. Nature, 458, pp. II 58 - I I 62.

OCDE. (20I3). Effective Carbon Prices. OECD Publishing.

Ploeg, F. v., \& Rezai, A. (20I6). Cumulative Emissions, Unburnable Fossil Fuel, and the Optimal Carbon Tax. Technological Forecasting \& Social Change, 7.

Sokolov, A., Stone, P., Forest, C., Prinn, R., Sarofim, M., Webster, M., et al. (2009). Probabilistic Forecast for Twentyfirst-century Climate based on
Uncertainties in Emissions (without Policy) and Climate Parameters. J Clim, 22, pp. 5I75-204.

Stavins, R. (20II). The Problem of the Commons: Still Unsettled After 100 Years. Am. Econ. Rev., I0I, pp. 8I- 108.

Stram, B. N. (20l4). A New Strategic Plan for a Carbon Tax. Energy Policy, 73: 519-523.

Taylor, D. D., Paiva, S., \& Slocum, A. H. (2017). An Alternative to Carbon Taxes to Finance Renewable Energy Systems and Offset Hydrocarbon based Greenhouse Gas Emissions. Sustainable Energy Technologies and Assessments, 19:136-145.

The World Bank. (n.d.). World Bank Open Data. Retrieved February I, 2017, from The World Bank Group: http://data.worldbank.org/

The World Bank; Ecofys. (2016). Carbon Pricing Watch 2016. Washington, DC: The World Bank.

Van Heerden, J., Gerlagh, R., Blignaut, J., Horridge, M., Hess, S., Mabugu, R., et al. (2006). Searching for Triple Dividends in South Africa: Fighting CO2 Pollution and Poverty while Promoting Growth. Energy J, 27(2), Pp. I|3-4|.

Weitzman, M. (20II). Fat-tailed Uncertainty in the Economics of Catastrophic Climate Change. Rev Environ Economic Policy, 5(2), pp. 275-92.

Zhao, Y.-H. (20II). The Study of Effect of Carbon Tax on the International Competitiveness of Energyintensive Industries: An Empirical Analysis of OECD 21 Countries, 1992-2008. Energy Procedia, 5:|29|1302.

Zhenxiang, W., Weijuan, L., \& Ti, W. (20II). The Impacts and Countermeasures of levying Carbon Tax in China under Low-carbon Economy. Energy Procedia, 5: 1968-1973.

Zhixin, Z., \& Ya, L. (20II). The Impact of Carbon Tax on Economic Growth in China. Energy Proceedia, 5:1757-I76I.

Zhou, S., Shi, M., Li, N., \& Yuan, Y. (20II). Impacts of Carbon Tax Policy on $\mathrm{CO} 2$ Mitigation and Economic Growth in China. Advances in Climate Change Research, 2(3): I24-I33. 